Proc. Estonian Acad. Sci. Eng., 2005, 11, 1, 59-68

\title{
A method for securing working mining block stability in Estonian oil shale mines
}

\author{
Jüri-Rivaldo Pastarus and Sergei Sabanov \\ Department of Mining, Tallinn University of Technology, Ehitajate tee 5, 19086 Tallinn, Estonia; \\ pastarus@cc.ttu.ee, sergei.sabanov@mail.ee \\ Received 6 February 2003, in revised form 9 October 2003

\begin{abstract}
This paper deals with the stability analysis and design of working mining blocks in Estonian oil shale mines, where the room-and-pillar mining with blasting is used. The pillars are arranged in a singular grid. Calculations are performed using the concepts of critical area and conditional thickness, and the sliding rectangle method. The results are presented in the form of conditional thickness contours. For practical applications, the criterion of the conditional thickness difference is used. It guarantees safety and minimal losses of the mining block. The method is applicable in different geological conditions, where the room-and-pillar mining is used.
\end{abstract}

Key words: working mining block, room-and-pillar mining, numerical modelling, stability, critical area, conditional thickness.

\section{INTRODUCTION}

The most important mineral resource in Estonia is a special kind of oil shale. It is located in a densely populated and rich farming district. The structure of the productive oil shale bed makes the rock difficult to break from the total massive. This is also one reason why shearer mining has been used. Underground oil shale production is obtained by room-and-pillar method with blasting. This method is cheap, highly productive, easy to mechanize and relatively simple to design.

Mining of oil shale has caused unfavorable environmental side effects accompanied by significant subsidence of the ground surface. It has caused a number of technical, economical, ecological and juridical problems. On the other hand, the collapse of a mining block stops the mining works. The first spontaneous collapse of pillars and surface subsidence in an Estonian oil shale mine took place in 1964. Up to the present, 73 collapses on the area of $100 \mathrm{~km}^{2}$ have been recorded. 
Design of mining block parameters is based on the instruction used in Estonian oil shale mines $\left.{ }^{1}\right]$. The actual roof and pillar dimensions depend on the quality of mining works. Consequently, pillar and roof dimensions vary from place to place within a mining block. If the difference between designed and actual parameters is large enough, the mining technology is disturbed and spontaneous collapse is likely to occur or the losses in pillars increase.

The aim of this investigation is to work out a method of optimal design of oil shale mines. The study consists of in situ observations, theoretical investigations and modelling on PC.

For stability analysis the concepts of critical area and conditional thickness as well as the sliding rectangle methods have been used previously $\left[^{2-5}\right]$. They are suitable for modelling on a PC. In this paper Visual Basic and MapInfo were used for numerical modelling. The results are presented as conditional thickness contours in a mining block map, which permit to determine the potential collapse parameters, its location and area. For practical application, the criterion of conditional thickness difference is used. For calculations, the conditional thickness limits for the critical area are determined. If the conditional thickness lies between these limits, a mining block is stable and losses are minimal. If the conditional thickness goes beyond the limits, the collapse is likely to occur or the losses increase. A method has been elaborated for designing the dimensions of the pillars of the next rows so that the pillars could quickly reach conditional thickness close to the calculated value. In this case the stability of a mining block and minimal losses are guaranteed.

This adaptive design method is applicable in different geological conditions, when the room-and-pillar mining is used. Applicability of the method has been demonstrated.

\section{GEOLOGY}

The commercially important oil shale bed is situated in the north-eastern part of Estonia. It stretches from west to east for $200 \mathrm{~km}$ and from north to south for $30 \mathrm{~km}$. The oil shale bed lays in the form of a flat bed, having a small inclination in southern direction. Its depth varies from 5 to $150 \mathrm{~m}$. The oil shale reserves in Estonia are estimated approximately at $4 \times 10^{9} \mathrm{t}$.

The oil shale seams occur among the limestone seams in the Kukruse Regional Stage of the Middle Ordovician. The commercial oil shale bed and its immediate roof consist of oil shale and limestone seams. The main roof consists of carbonate rocks of various thicknesses. The characteristics of various oil shale and limestone seams are different. The strength of the rocks increases in the southward direction. The compressive strength of oil shale is $20-40 \mathrm{MPa}$ and that of limestone $40-80 \mathrm{MPa}$. The volume density is $1.5-1.8 \mathrm{Mg} / \mathrm{m}^{3}$ and $2.2-2.6 \mathrm{Mg} / \mathrm{m}^{3}$, respectively. The calorific value of dry oil shale is about $7.5-18.8 \mathrm{MJ} / \mathrm{kg}$ depending on the seam and the location in the deposit. 


\section{CURRENT MINING SYSTEM}

In Estonian oil shale mines the room-and-pillar mining system with blasting is used. It gives the extraction factor about $80 \%$. The oil shale bed is embedded at the depth of 40-70 m. The field of an oil shale mine is divided into panels, which are subdivided into mining blocks, approximately $300-350 \mathrm{~m}$ in width and $600-800 \mathrm{~m}$ in length each. A mining block usually consists of two semi-blocks. The height of the room is $2.8 \mathrm{~m}$. The room is very stable when it is $6-10 \mathrm{~m}$ wide. However, in this case the bolting must still support the immediate roof. The pillars in a mining block are arranged in a singular grid. Actual mining practice has shown that pillars with a square cross-section $\left(30-40 \mathrm{~m}^{2}\right)$ are the best. A work cycle lasts for over a week.

\section{THE METHOD OF ADAPTIVE DESIGN}

The stability and losses of a mining block depend on the choice of the pillar and room dimensions. For these calculations, an instruction for Estonian oil shale mines has been elaborated $\left[{ }^{1}\right]$. It includes methods for calculating the optimum parameters of the roof, pillars and support, based on long-term investigations of oil shale mines. On the other hand, it is known that the actual dimensions of the roof and pillars depend on the applied technology and quality of mining works. Consequently, the pillar and roof dimensions vary from place to place within a mining block. Due to the complicated structure of the pillars and roof, their stability analysis demands special calculation methods. For the analysis the concept of critical width, methods of conditional thickness and sliding rectangle $\left[{ }^{2,5}\right]$ were used.

The pillar load depends on the width of the mining block. Thus the concept of the critical width is to be used. The critical width is the greatest width that the rock above the mine can span before its failure, or, if there are pillars, the width we must mine before the pillars load-bearing capacity is completely used $\left[^{3}\right]$. In fact, the best indicator of critical width in a given situation will be provided from old mine maps, by records of failure and surface subsidence and from measuring roof-to-floor convergence in the mines. For Estonian oil shale mines critical width $L$ is determined as $\left.{ }^{4,5}\right]$

$$
L=1.2 H+10
$$

where $H$ is the thickness of the overburden rocks.

In the three-dimensional case, the critical width becomes the critical area. The latter is the area by which the destruction of the pillars and surface subsidence becomes possible. Usually, the collapse begins in one critical area (potential collapse centre) and then extends to the barrier pillars. 


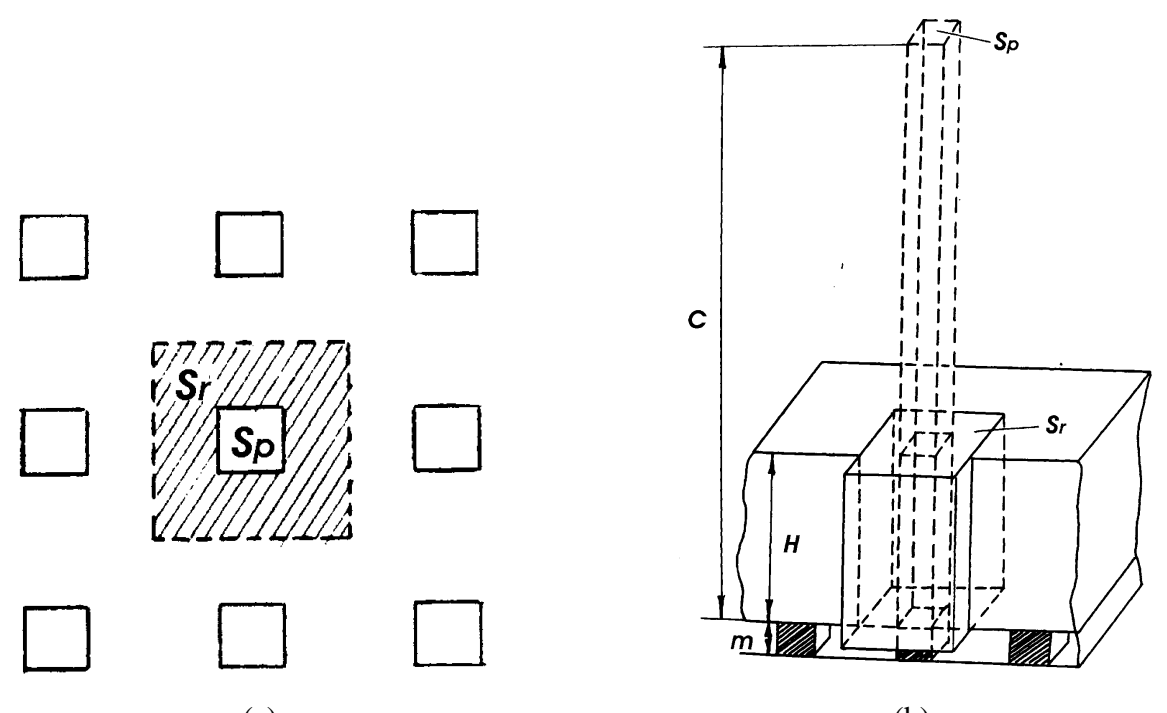

(a)

(b)

Fig. 1. Definition of the geometrical parameters.

The load on the pillar depends on the real parameters of the pillar and roof. To characterize them, two parameters, the support coefficient $K$ and the conditional thickness $C$, are used $\left[{ }^{2,6}\right]$.

Conditional thickness $C$ is calculated as (Fig. 1) $\left.{ }^{2,6}\right]$

$$
C=\frac{H}{K}, \quad K=\frac{S_{\mathrm{p}}}{S_{\mathrm{r}}},
$$

where $S_{\mathrm{p}}$ is the cross-sectional area of the pillar, $S_{\mathrm{r}}$ is the roof area per pillar, $H$ is the thickness of the overburden rocks and $K$ is the support coefficient. Conditional thickness is the height of a prism whose cross-section equals that of a pillar and whose volume equals the volume of the overburden rocks above the roof area.

Conditional thickness includes sufficient information and is suitable for stability calculations. Conditional thickness is related to the stress in the pillar as follows:

$$
\sigma=C \gamma
$$

where $\sigma$ is the normal stress at the top of the pillar and $\gamma$ is the weight density of the overburden rocks.

If the load is too high, a failure of the pillars is possible. Conditional thickness for the critical area $C_{\mathrm{c}}$ can be expressed as $\left.{ }^{7}\right]$ : 


$$
C_{\mathrm{c}}=\frac{H_{\mathrm{a}} L^{2}}{\sum S_{\mathrm{p}_{i}}}
$$

where $H_{\mathrm{a}}$ is the average thickness of the overburden rocks in the critical area and $S_{\mathrm{p}_{i}}$ is cross-sectional area of the $i$ th pillar in the critical area.

By the sliding rectangle method $\left.{ }^{2,5}\right]$, the conditional thickness of the critical area must be determined everywhere inside a mining block. The results are presented by conditional thickness contours. The relative uncertainty in conditional thickness is $1.5 \%$ at the $95 \%$ confidence level. The presented method permits to determine the centre and area of a potential collapse in a mining block.

The mining block stability and losses in pillars depend on the actual parameters of the pillars and roof. The variation in conditional thickness parameters in a real mining block is illustrated in Fig. 2. One can see that the conditional thickness fluctuates around the designed value. If the conditional thickness remains between lower and upper limits, the mining block is stable and losses in mineral resources are minimal. If the conditional thickness is out of the limits, either the collapse is likely to occur (area a) or the losses increase (area b).

The idea of the adaptive design of the mine lies in selecting the parameters of the next mining area so that the conditional thickness lies in the prescribed limits. This method is illustrated in Fig. 3.

Let us assume that in the critical area (I) the conditional thickness exceeds the limits. We must choose cross-sectional area of the pillars of the new row (7n) so that the conditional thickness of the critical area II remains between the upper and lower limits. If it is not possible, we must change the parameters of the pillars of the next row ( $8 \mathrm{n}$, critical area III) and repeat this process until the purpose is reached.

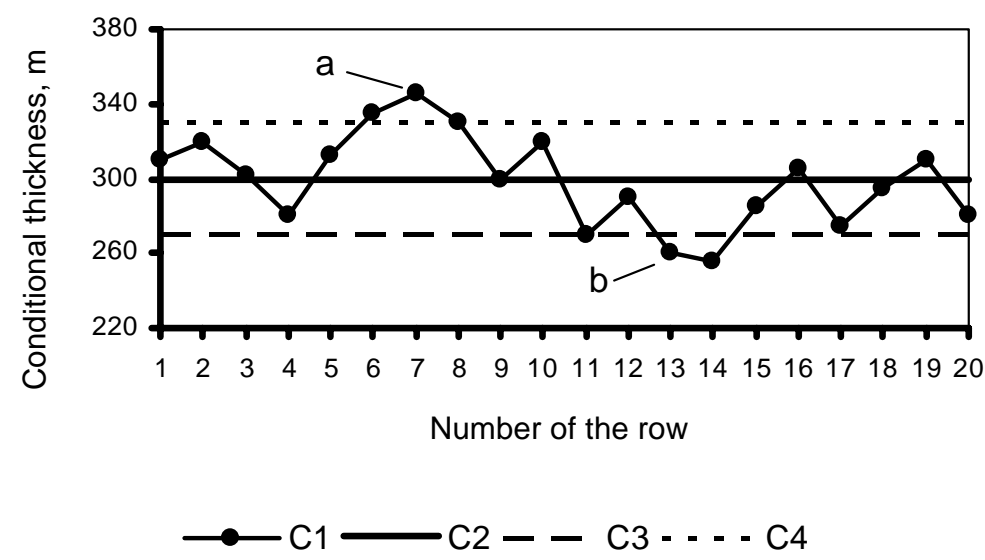

Fig. 2. Variation of the conditional thickness in a mining block: a - collapse is possible; $b$ - losses in mineral resources are increased; $\mathrm{C} 1$ - actual conditional thickness in the critical area; $\mathrm{C} 2$ designed value of the conditional thickness; C3 - lower limit; C4 - upper limit. 


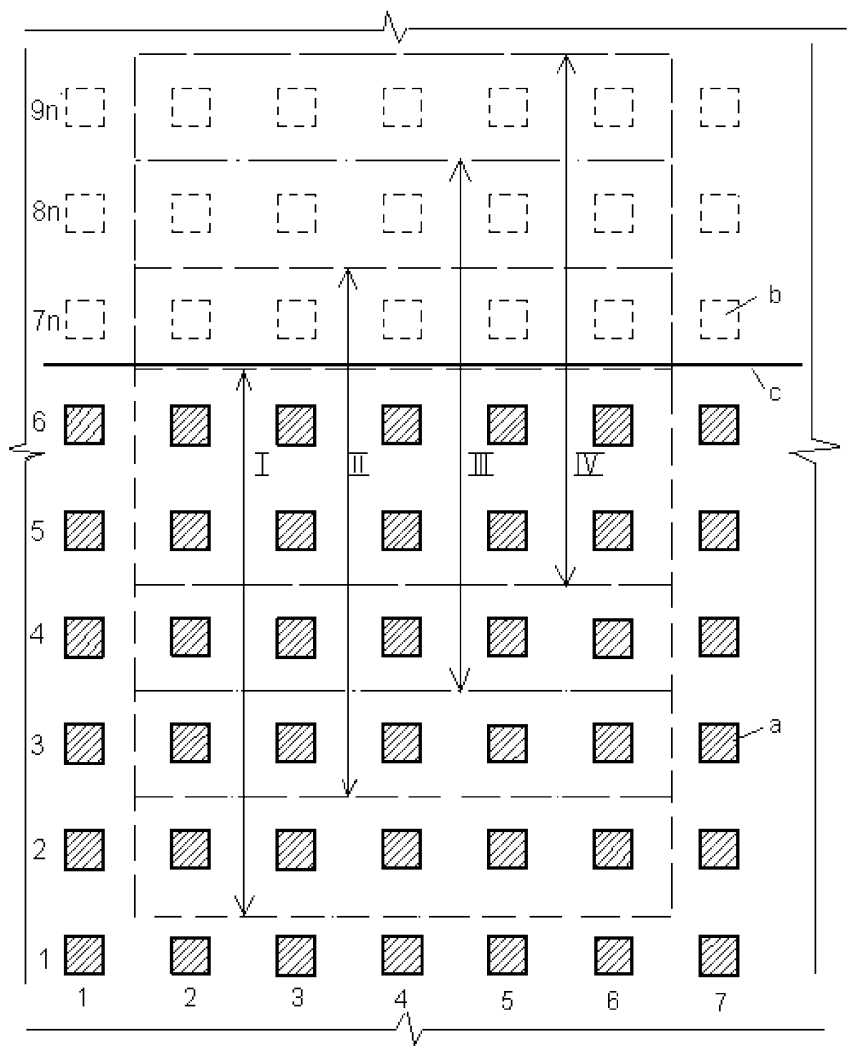

Fig. 3. Method for designing dimensions of the new rows: $a$ - actual pillars; $b$-designed pillars; c-stope; I - critical area where the conditional thickness exceeds the limit; II, III, IV - critical areas for designing the parameters of new rows of the pillars.

\section{APPLICATION}

The applicability of the method is demonstrated on the example of the mining block No. 705 of the Estonia Mine. The commercial oil shale bed with the thickness of $2.8 \mathrm{~m}$ is embedded in the depth of $53 \mathrm{~m}$. The mining block is bordered by barrier pillars. The optimum conditional thickness (designed value) is $267 \mathrm{~m}$. The dimensions of the critical area are $74 \times 74 \mathrm{~m}$.

Investigations of the real situation have shown that by using blasting works, the random deviation of the actual pillar and roof parameters from the designed ones does not exceed $\pm 1 \mathrm{~m}$. Statistical analysis showed that on average the deviation of the conditional thickness in the sliding rectangle differs from the designed one for $\pm 7 \%$. Upper and lower limits of the conditional thickness are 284 and $250 \mathrm{~m}$, respectively.

Parameters of the working mining block show that in the left semi-block a potential collapse area of conditional thickness $C=310 \mathrm{~m}$ (Fig. 4) is present. 


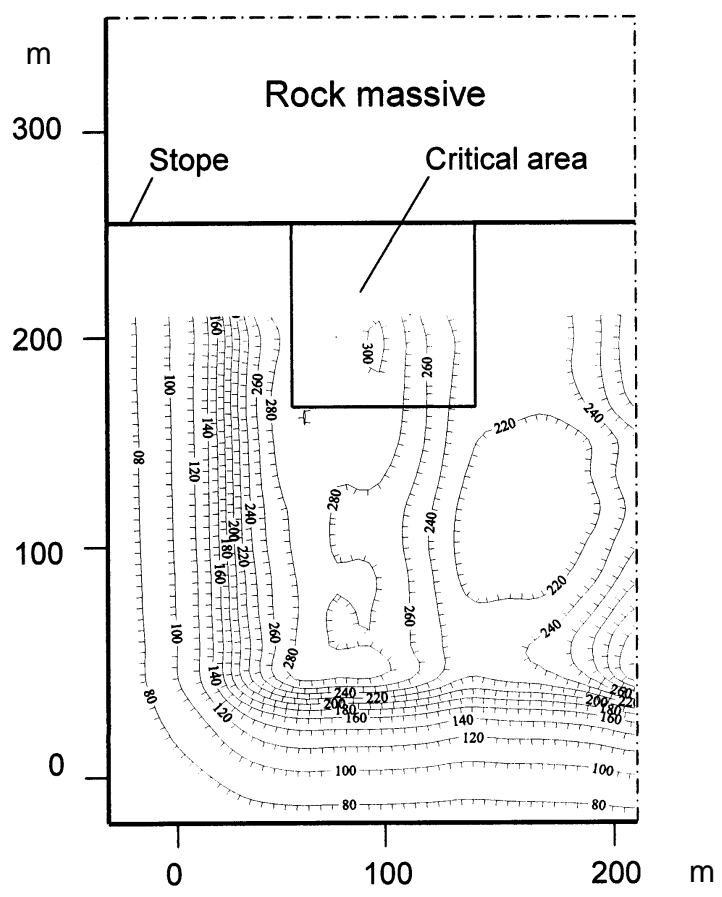

Fig. 4. Conditional thickness of a working mining block; Estonia Mine, block No. 705.

It is clear that the conditional thickness exceeds the limit and collapse is possible. It is possible to increase the cross-sectional area of the next row pillars to avoid collapse. The design of the pillar dimensions may be performed using three methods.

1. The cross-sectional area of pillars in the critical area is constant and equals the designed value. The conditional thickness varies (Fig. 5). In this case the conditional thickness approaches slowly the designed value and a large potential collapse area is present. The stability of the mining block is not guaranteed. The method is not applicable in practice.

2. The conditional thickness in the critical area is constant and equals the designed value. The cross-sectional area of new pillars in the next rows varies (Fig. 6). It is clear that the cross-sectional area of the pillars of the first designed row is very large. The cross-sectional area of the next row pillars is small (rows from 4 to 8). Application of this method is technologically complicated.

3. For practical applications the cross-sectional area $S_{\mathrm{p} n}$ of the pillar of the next row is determined as

$$
S_{\mathrm{pn}}=\frac{C_{\mathrm{r}} S_{\mathrm{pd}}}{C_{\mathrm{d}}}
$$


where $C_{\mathrm{r}}$ is real conditional thickness, $C_{\mathrm{d}}$ is the designed value of the conditional thickness and $S_{\mathrm{pd}}$ is designed value of the cross-sectional area of the pillars. This method guarantees a quick and smooth approach of the conditional thickness and the cross-sectional area of the pillars to the designed values (Figs. 7 and 8).

It is obvious that the values of the conditional thickness and dimensions of the cross-sectional area of the pillars quickly approach the calculated value. In this case one must modify only the pillar parameters of the next three rows. There appears a potential collapse area, but it is small and not dangerous. The presented method has been successfully applied in practice.

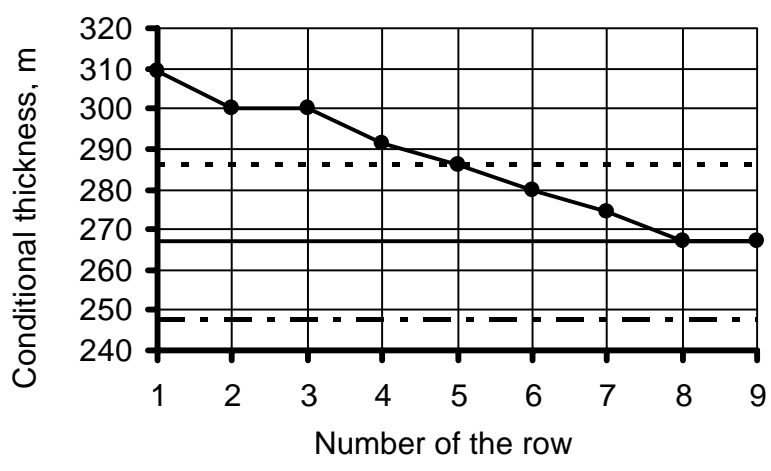

$\longrightarrow \mathrm{C}_{1}-\mathrm{C}_{2}--\mathrm{C}_{3}-\mathrm{CC}_{4}$

Fig. 5. Changes in the conditional thickness in the critical area at a constant cross-sectional area of the pillars in the case of the first method: $\mathrm{C} 1$ - actual conditional thickness in the critical area; $\mathrm{C} 2$ calculated value of the conditional thickness; C3 - lower limit; C4 - upper limit.

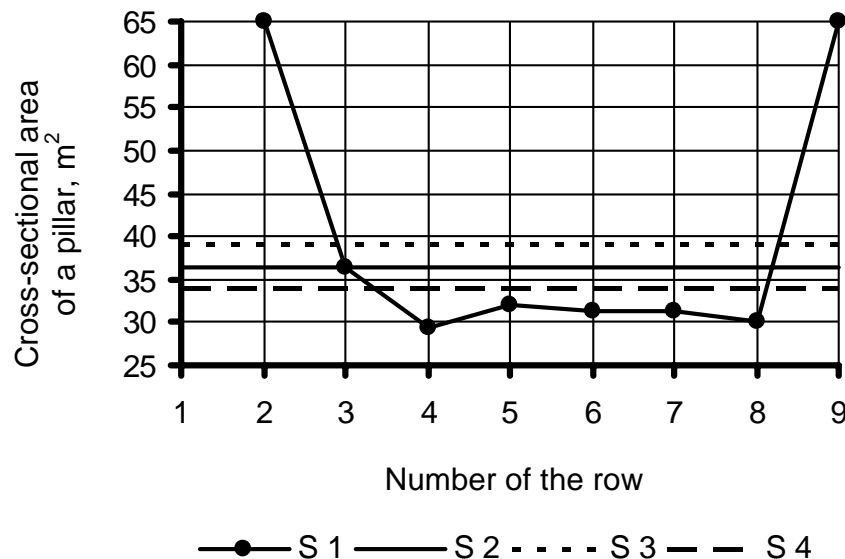

Fig. 6. Changes in the cross-sectional area of the pillars at a constant conditional thickness in the case of the second method: S1 - actual cross-sectional area of the pillar; S2 - calculated value of the cross-sectional area of a pillar; S3 - upper limit; S4 - lower limit. 


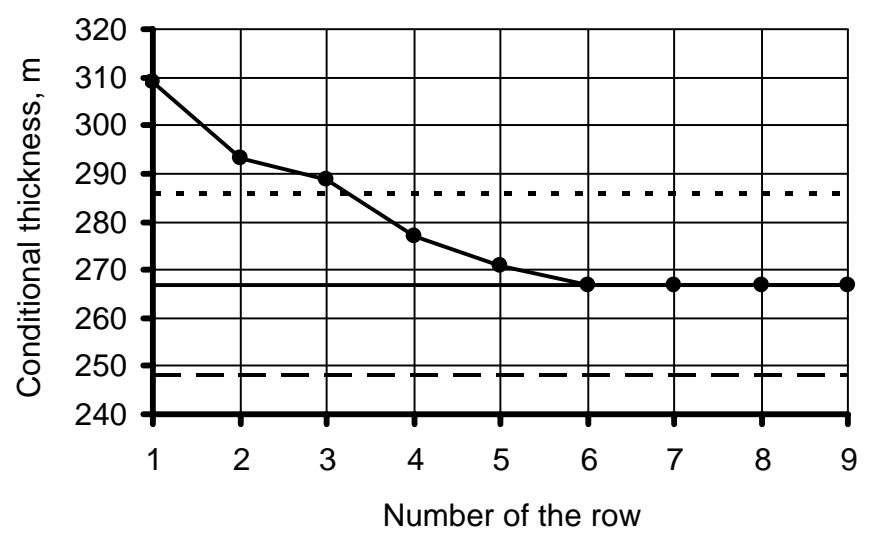

$\longrightarrow \mathrm{C}_{1} \longrightarrow \mathrm{C}_{2}-\mathrm{C}_{3} \ldots \mathrm{C} 4$

Fig. 7. Approach of the conditional thickness to the designed value if the third method is used: $\mathrm{C} 1-$ actual conditional thickness in the critical area; $\mathrm{C} 2$ - calculated value of the conditional thickness; C3 - lower limit; C4 - upper limit.

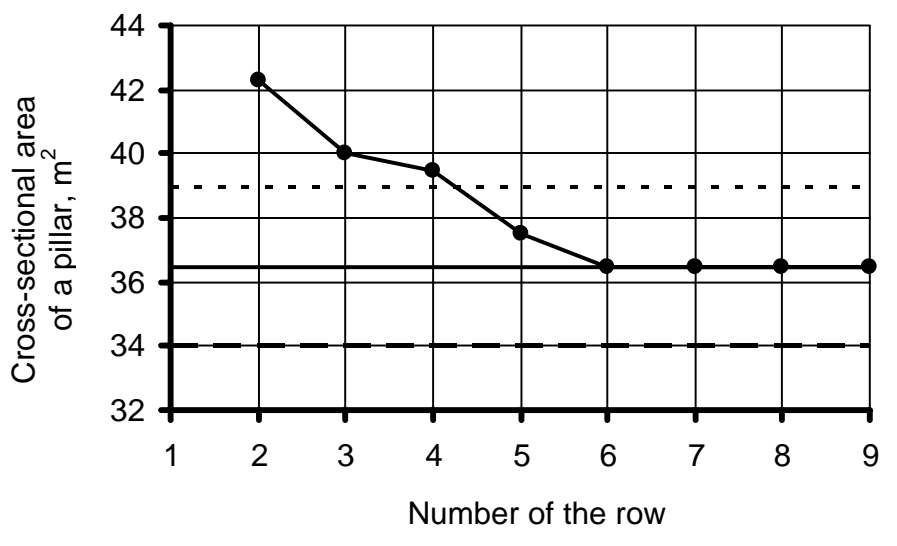

$\longrightarrow S_{1} \longrightarrow S_{2} \ldots S_{3}-S_{4}$

Fig. 8. Character of the approach of the cross-sectional area of the pillars to the designed value if the third method is used: S1 - actual cross-sectional area of the pillar; S2 - calculated value of the cross-sectional area of a pillar; S3 - upper limit; S4 - lower limit.

\section{CONCLUSIONS}

Stability of the pillars and roof, and the extraction of the maximum amount of oil shale are achieved, if the average conditional thickness in the critical area is in the range of $\pm 7 \%$ from the designed value. If these limits are exceeded, one must increase or decrease the pillar cross-sectional area in the next rows. A method for designing the parameters of the pillars for the next rows has been suggested. This 
method is applicable in different geological conditions where the room-and-pillar mining is used. An application of this method has been described.

\title{
ACKNOWLEDGEMENT
}

This research was supported by the Estonian Science Foundation (grant No. 5164).

\section{REFERENCES}

1. Maapõueseadus ja selle rakendamise õigusaktid II. Keskkonnaministeerium, Majandusministeerium. Trükkal, Tallinn, 1998.

2. Talve, L. Check-up of real parameters of room-and-pillar mining in Estonia's oil shale mines. Trudy Tallinskogo Politekhnicheskogo Instituta, 1978, No. 451, 23-55 (in Russian).

3. Parker, I. Mine pillar design in 1993: Computers have become the opiate of the mining engineers. Min. Eng., 1993, July, 714-717; August 1047-1050.

4. Stetsenko, V. and Ivanov, G. Prognosis of the time depending roof displacements for different span lengths. Oil Shale, 1981, 11, 13-18 (in Russian).

5. Pastarus, Yu.-R. V. and Nikitin, O. V. Estimation methods for stability of mining excavations (on the example of the oil shale deposits in Estonia). Gornyj Zhurnal, 2003, No. 4/5, 71-75 (in Russian).

6. Pastarus, J.-R. and Toomik, A. Roof and pillar stability prognosis in Estonian oil shale mines. In Proc. ISRM Regional Symposium EUROCK 2001, "Rock Mechanics - a Challenge for Society” (Särkka, P. and Eloranta, P., eds.). Balkema, Lisse, Abingdon, Exton (PA), Tokyo, Espoo, 2001, 849-853.

7. Pastarus, J.-R. and Toomik, A. Subsidence prediction in Estonia's oil shale mines. In Proc. Sixth International Conference on Environmental Issues and Management of Waste in Energy and Mineral Production - SWEMP 2000 (Singhal, R. K. and Mehrotra, A. K., eds.). Balkema, Rotterdam, Brookfield, Calgary, 2000, 225-229.

\section{Töötava kambriploki stabiilsuse tagamine Eesti põlevkivikaevandustes}

\author{
Jüri-Rivaldo Pastarus ja Sergei Sabanov
}

On käsitletud töötava kambriploki stabiilsusanalüüsi ja kaevanduse adaptiivset projekteerimist Eesti põlevkivikaevandustes, kus on kasutusel puur-lõhketöödega kamberkaevandamisviis. Lähtutud on sellest, et kaevanduse praktilisel laiendamisel võib tekkida ekvivalentse sügavuse kõrvalekalle projekteeritust. Selle tulemuseks võivad olla kaevanduse ebastabiilsus või liigsed kaod. On tehtud ettepanek jälgida perioodiliselt ekvivalentse sügavuse vastavust projekteeritule. Kõrvalekalde ilmnemisel korrigeeritakse järgmiste tervikute põiklõikeid, kasutades selleks valemit (5). Nii tagatakse ekvivalentse sügavuse jäämine etteantud piiridesse. 